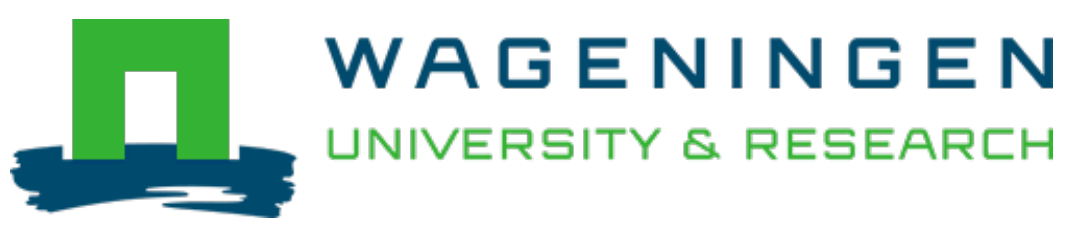

\title{
New organizational forms in emerging economies : bridging the gap between agribusiness management and international development
}

\author{
Journal of Agribusiness in Developing and Emerging Economies \\ Dentoni, Domenico; Bijman, Jos; Bossle, Marilia Bonzanini; Gondwe, Sera; Isubikalu, Prossy et al \\ https://doi.org/10.1108/JADEE-10-2019-0176
}

This article is made publicly available in the institutional repository of Wageningen University and Research, under the terms of article $25 \mathrm{fa}$ of the Dutch Copyright Act, also known as the Amendment Taverne. This has been done with explicit consent by the author.

Article 25 fa states that the author of a short scientific work funded either wholly or partially by Dutch public funds is entitled to make that work publicly available for no consideration following a reasonable period of time after the work was first published, provided that clear reference is made to the source of the first publication of the work.

This publication is distributed under The Association of Universities in the Netherlands (VSNU) 'Article $25 \mathrm{fa}$ implementation' project. In this project research outputs of researchers employed by Dutch Universities that comply with the legal requirements of Article $25 \mathrm{fa}$ of the Dutch Copyright Act are distributed online and free of cost or other barriers in institutional repositories. Research outputs are distributed six months after their first online publication in the original published version and with proper attribution to the source of the original publication.

You are permitted to download and use the publication for personal purposes. All rights remain with the author(s) and / or copyright owner(s) of this work. Any use of the publication or parts of it other than authorised under article $25 \mathrm{fa}$ of the Dutch Copyright act is prohibited. Wageningen University \& Research and the author(s) of this publication shall not be held responsible or liable for any damages resulting from your (re)use of this publication.

For questions regarding the public availability of this article please contact openscience.library@wur.nl 


\section{GUEST EDITORIAL New organizational forms in emerging economies: bridging the gap between agribusiness management and international development}

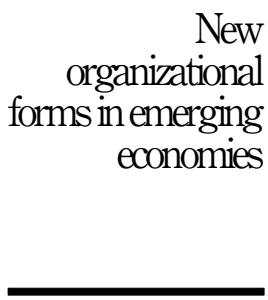

Received 22 October 2019 Revised 28 October 2019 Accepted 28 October 2019

New

organizational economies

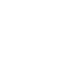

\author{
Domenico Dentoni, Jos Bijman, Marilia Bonzanini Bossle, \\ Sera Gondwe, Prossy Isubikalu, Chen Ji, Chintan Kella, \\ Stefano Pascucci, Annie Royer and Luciana Vieira \\ (Information about the authors can be found at the end of this article.)
}

\begin{abstract}
Purpose - This editorial article introduces and analyzes a variety of new organizational forms that rapidly emerged in Africa, Asia, Latin America and Eastern Europe in the latest two decades. Among the others, these include: business model partnerships, business platforms, incubators and hubs, public-private partnerships, agribusiness companies' foundations and spin-offs, short supply chains, community-supported agriculture and other community self-organizing experiences. Building upon the recent literature and the five selected papers in this special issue, the authors discuss what is novel in these organizations and why, when and how they emerge and evolve over time.

Design/methodology/approach - The authors identify three elements that, when considered together, explain and predict the emergence and evolution of these new organizational forms: institutions, strategies and learning processes.

Findings - The authors demonstrate that societal actors seeking to (re)design these new organizational forms need to consider these three elements to combine the pursuit of their interests of their own constituencies with the sustainable development goals (SDGs).

Originality/value - Taking stock from the literature, the authors invite future research on new organizational forms to take explicitly the pursuit of the SDGs into consideration; to build upon a process ontology; and to deeply reflect on our positionality of scientists studying and sometimes engaging in these organizations.
\end{abstract}

Keywords Organizational change, Organizational innovation, Partnerships, Value chains, Sustainable development goals

Paper type Editorial

\section{New organizational forms: What are they? Why should we study them?}

Several novel organizational forms have been emerging in Africa, Asia, Latin America and Eastern Europe - what we will loosely refer in this Special Issue as emerging economies along agricultural and food value chains since the early 2000s. These organizational forms involve, among the others: business model partnerships seeking to establish economically viable collaborations while involving also actors outside value chains (e.g. nongovernmental organizations, extension agents, community leaders); business platforms, incubators and hubs aiming to foster entrepreneurial and innovative agrifood ecosystems; a new generation of

The coordination of this Special Issue has been sponsored with generous funding from Climate Change, Agriculture and Food Security (CCAFS) and the Dutch Scientific Organization (NWO) to the projects titled "Organizing structures of business models for SMAllholder Resilience" (OSMARE), 4th Global Challenges Program, and "Entrepreneurial Learning in Inclusive Agribusiness" (ELIA), Senior Expert Program (SEP). 
cooperatives and producers' organizations fostering their market orientation; public-private partnerships involving stakeholders across government, business and civil society sectors to develop and regulate private standards and/or promoting and assessing sustainability practices; agribusiness companies' foundations and spin-offs investing, for example, in new technologies for climate change mitigation or social impact innovations in collaboration with other public or civil society stakeholders; short supply chains or community-based enterprises seeking to establish long-term economic sustainability. While organizational forms have always evolved from their predecessors, we seek to understand what leads to novelty in them. Rather than the actors involved, the novelty lays in the way these actors partner or collaborate with each other, making their natural, financial, physical, human, technological and social resources complementary in more complex ways than in traditional agrifood value chain with its linear buyer-supplier or supplier-supplier collaborations.

By bringing new organizational forms in emerging economies to the fore of the debate, this Special Issue speaks to policymakers, agribusiness managers and civil society leaders - as well as researchers in agrifood value chains engaging with them - that design, organize or reshape partnerships to address the urgent, complex problems of climate change, poverty, food insecurity and malnutrition and even conflicts related to access to natural resources. These stakeholders realize that the state, private actors or civil society cannot tackle societal and environmental problems alone, nor can they seize growth opportunities typical of emerging economies, without new and more collaborative forms of organizing. On the one hand, changes in development cooperation policies among Western countries, notably "from aid to trade", give increasing priority to private economic development, with substantial amounts of subsidies now going into intervention programs that are directly linked to the business interests of domestic and foreign (i.e. from the donor country) private companies. On the other hand, the financial crisis of 2007/2008, the price volatility of staple grains and the increasing commercial pressure on land and other natural resources suggest that unrestrained free-market approaches are a risk rather than a solution for food security and poverty reduction. On the basis of this realization, stakeholders have been building new collaborative partnerships that conjugate the pursuit of social, environmental and commercial goals to more fundamentally address the sustainable development goals (SDGs), at both local and global scales.

How does this Special Issue contribute to informing our targeted audience? Our editorial team composed of ten social scientists with agrifood expertise across five continents (Africa, Latin America, North America, Europe and South-East Asia) argues that the recent scientific literature describing the structure and impacts of new organizational forms in emerging economies is vast, yet polarized. This polarization has a disciplinary and perhaps even a political nature. On the one hand, the field of agribusiness management looks at the dominant role of the private sector in new organizational forms focusing on its potential for reaching the SDGs through partnerships counting on the technological, financial and managerial resources pooled by large private investors (Likoko and Kini, 2017). On the other hand, the literature on international development finds little empirical support on the role of these organizational forms in addressing issues such as poverty, food insecurity and climate change (Bitzer and Glasbergen, 2015). One stream in this literature sees new organizational forms - especially those led by large private companies - as ways of gaining and maintaining control over strategic and increasingly scarce agricultural resources, thus establishing or maintaining unbalanced power relations in emerging economies (Chamberlain and Anseeuw, 2019). These two scientific worlds look at each other with (perhaps justified) reciprocal suspicion and hardly communicate through scientific debate. Our Special Issue - although based in a journal and personal expertise with a background primarily in agribusiness management - aims to act as a platform for building a stronger interdisciplinary and 
transdisciplinary debate, thereby bridging the gap between agribusiness management and international development.

Hence, to provide such a platform for interdisciplinary and transdisciplinary research and action, this Special Issue seeks to address the controversies that polarize the debate. While increasingly deemed as necessary, experimenting with new organizational forms in emerging economies involves several controversies that our targeted audience needs to be informed about. First of all, there is the question whether these new organizational forms - in their market-driven efforts to rapidly reach the SDGs at scale - are able to support socioeconomic inclusion of marginalized actors. In other words, what is the trade-off between aiming for socioeconomic inclusion and maintaining competitiveness in the long run (Lutz and Tadesse, 2017)? While sustaining their competitive advantage, are the companies involved in new organizational forms indeed able to prioritize the SDGs? When finding a reasonable balance between financial viability and socioeconomic inclusion, do these partnerships support or hamper climate adaptation and mitigation? To meaningfully address these questions, we argue that our audience needs to zoom into the details of how new organizational forms establish and change over time given the institutional and agroecological conditions of the region in which they are embedded. Building upon another recent special issue of the Journal of Agribusiness in Developing and Emerging Economies, on value chains as complex adaptive systems, we suggest that the functioning and impacts of these new organizational forms can be best assessed in their interplay with the local but changing circumstances (Orr et al., 2018). Hence, the rest of this editorial provides some core elements necessary to understand and explain why, when and how these new organizational forms in emerging economies emerge and evolve over time and therefore, how the analysis of these elements is essential to inform the ongoing academic, policy and managerial debates.

\section{Why, when and how do new organizational forms emerge and evolve?}

Understanding and explaining why, when and how new organizational forms emerge and evolve in emerging economies is essential to be able to design, support or change them in their pursuit to include SDGs. To address this question, we propose a theoretical framework (see Figure 1) that builds upon various strands of literature on new organizational forms, including from our own research experience and from the papers selected for this Special Issue. Overall, this framework suggests that new organizational forms develop and change over time on the basis of (1) the institutions in which they are embedded, (2) the strategies that their members pursue individually and collectively and (3) the learning processes that members engage in individually and collectively. In the following paragraphs we discuss these three key elements of new organizational forms and their interdependencies in various contexts of emerging economies.

First, the structure and evolution of new organizational forms can be explained through the institutions that they are embedded in, that is, the societal "rules of the game" that organizations are subject to (North, 1990, 1991). These rules of the game can be formal (e.g. laws, policies and standards at international, national or subnational level) or informal (e.g norms, customs, traditions, values and identities that actors bring into these new organizational forms) (Scott, 1987; Thornton and Ocasio, 2008). Institutions shape new organizational forms in emerging economies in several ways. When formal laws or standards are absent or not well enforced and implemented, thus generating uncertainty in the outcomes of transactions and relationships among partners, partnerships will develop organizational structures that compensate for this uncertainty (Menard, 2017). For example, in countries with little or slow enforcement of contract laws, new organizational forms develop internal mechanisms for the resolution of disputes, such as in the Agricultural Commodity Exchange of Malawi (Dentoni and Dries, 2015) or in the Roundtable for 


\section{JADEE}

Figure 1.

Elements of new organizational forms in emerging economies

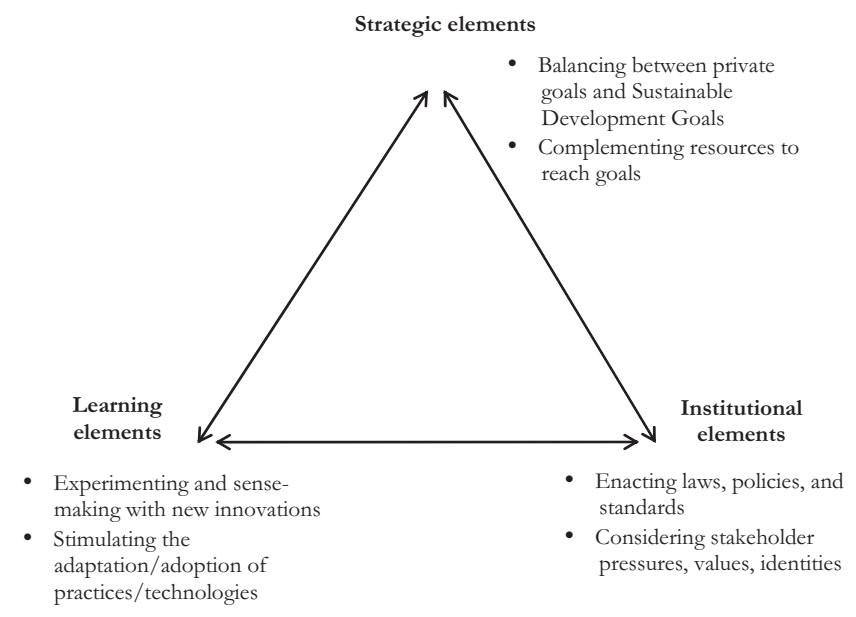

Sustainable Palm Oil in Indonesia (Schouten and Glasbergen, 2011). Or, when pressures from stakeholders or the values and identities of the members are sensitive to cultural (e.g. ethnic and religious; Abebe et al., 2016), social or ecological issues (Bossle et al., 2016), partnerships develop organizational practices that enact these informal institutions. For example, the same initial design of business model partnership in the Malawian dairy sector evolved differently when applied in two different subnational local contexts because of their notable sociocultural differences (Cucchi et al., 2019).

Second, the strategies of the actors involved in these new organizational forms influence their structure and evolution. These strategies involve the organizational goals of each partner, the goals that partners share in founding a partnership (Bengtsson and Kock, 2000) and the complementarity of the resources that each actor brings to the partnership (Das and Teng, 2000; Clarke and MacDonald, 2019). In several contexts of emerging economies, agribusiness companies, local governments, international organizations, nongovernmental organizations (NGOs) and farmers (including their producer organizations) partner with each other realizing they need each other's resources in the pursuit of goals (Royer et al., 2017). For example, it has been classically observed that agribusiness companies need NGOs to organize the large group of dispersedly living small-holder suppliers. NGOs often need agribusiness companies to establish economically viable ways for farmers to adapt to climate changes or reduce poverty and food insecurity. Private actors - both profit and nonprofit - often need the government to develop an enabling environment for the pursuit of both private goals and SDGs. And, last but not least, these actors increasingly need to partner with farmers and their organizations, given the increasingly scarce nature of their resources (Vieira et al., 2016). Or, as an alternative, the influx of private investment in Africa and Asia - either privately or publicly supported - has brought changes in the ownership of land, where (new) owners have experimented with new organizational forms, ranging from pure wage labor, share-cropping to outsourcing and joint ownership (e.g. see Ji et al., 2017 in China). How partners build resource complementarities in these new organizational forms is better understood in relation to their strategic goals (Menard, 2004, 2018). In particular, given the increased urgency of addressing sustainability issues, this resource complementarity can be understood on how partners balance between, or align, the pursuit of collective SDGs and the interests of their own constituencies (Voegtlin and Scherer, 2017; Antwi-Agyei et al., 2018).

Third, the structure and evolution of new organizational forms need to be understood through the learning processes occurring within them. Learning in new organizational 
forms occurs on several levels (including, among others, at a collective and individual level) and in several ways (from planned to serendipitous). At a collective level, the novelty itself of these partnerships implies that partners are called - especially in early stage of organizational development - to experiment, reflect and adapt how to collaborate to reach mutually agreed goals (Dentoni et al., 2016, 2018). Depending on whether and how these learning cycles are acknowledged and communicated to partners and stakeholders involved, new organizational forms may structure and evolve along different pathways (Bitzer and Bijman 2015. For example, some new organizational forms led by food companies currently "re-inventing the wheel," that is, allocating limited resources to learn from their partners' history in doing business with small-holder supply chains in emerging economies (Bitzer and Bijman, 2014). Furthermore, learning in new organizational forms occurs at individual level: in particular, learning may be set as an intermediate, necessary target to ultimately fulfill both private goals and the SDGs. For example, innovation platforms - which recently spread across Sub-Saharan Africa and, to a minor extent, Latin America and Asia - provide space for stakeholders in local agrifood systems (i.e. at district or subdistrict level). In these platforms, farmers share knowledge from each other in relation to the local challenges (e.g. climate-related pests and diseases, changing agroecological conditions, institutional and policy changes or issues with access to markets and finance). As evidence shows that not all farmers learn equally through their participation to innovation platforms (Barzola et al., 2019), more focused efforts are currently taking place to support the learning process of actors in farming communities that are more at risk of marginalization, such as women and youth (e.g. setting up farmer field schools; see Isubikalu, 2007 in Uganda) or, more recently, farmer business schools with a gender and youth focus; see Kawarazuka and Kharchandy 2019 in India, or Naziri and Enalbes 2019 in The Philippines).

\section{Contribution of the papers in this special issue}

The five selected papers in this Special Issue provide vivid illustrations of how the interplay of institutional, strategic and learning elements shapes the structure, functioning and evolution of new organizational forms in emerging economies. Table 1 illustrates that, all together, these papers analyze a variety of new organizational forms, embedded in different geographical contexts and scales, and use a variety of analytical methods. In this introductory article, we synthesize and interpret the contribution that each of these five papers (presented in alphabetical order) makes to the literature on new organizational forms in emerging economies.

The first paper of this special issue by Barzola $e t$ al. reports the findings of a systematic literature review on how multistakeholder platforms influence farmers' innovation. This systematic review synthesizes 44 papers published between 2005 and 2018 and predominantly grounded in Sub-Saharan Africa. Findings illustrate that, first of all, the peculiar feature of multistakeholder platforms as new organizational forms in emerging economies lays in the physical and/or virtual interface set to pool and exchange knowledge multilaterally among the several stakeholders involved. Second, depending on their established goals and activities (i.e. capacity-building, network-building, planning, aligning with policies or facilitating communication), multistakeholder platforms may support innovation at different levels (i.e. at farmer household level, farm level, value chain level, local or global institutional level). Through these findings, this paper provides a comprehensive illustration on how the strategies of new organizational forms in emerging economies shape their learning processes (Strategies $\rightarrow$ Learning link in Figure 1).

Grounded on a literature review of and three empirical case study from the state of Rio Grande do Sul (Brazil), the second paper of this special issue by Guarnieri et al. analyzes condominiums of rural warehouses. These condominiums are relatively new organizational forms because, while first appeared in the 1980s, they thrived across southern Brazil and 


\begin{tabular}{|c|c|c|c|c|}
\hline \multirow[t]{2}{*}{ JADEE } & Authors & $\begin{array}{l}\text { New organizational form } \\
\text { (and context) }\end{array}$ & $\begin{array}{l}\text { Elements of new organizational forms } \\
\text { analyzed }\end{array}$ & Methods \\
\hline & Barzola et al. & $\begin{array}{l}\text { Multistakeholder platforms } \\
\text { (global, predominantly } \\
\text { Sub-Saharan Africa) }\end{array}$ & $\begin{array}{l}\text { Strategies } \rightarrow \text { Learning: The collectively } \\
\text { set goals and expected outcomes } \\
\text { influence which levels of agricultural } \\
\text { innovation are achieved }\end{array}$ & $\begin{array}{l}\text { Systematic } \\
\text { literature review }\end{array}$ \\
\hline & $\begin{array}{l}\text { Guarnieri } \\
\text { et al. }\end{array}$ & $\begin{array}{l}\text { Condominiums of rural } \\
\text { warehouses (Rio Grande do } \\
\text { Sul, Brazil) }\end{array}$ & $\begin{array}{l}\text { Strategies } \rightarrow \text { Institutions: Reducing } \\
\text { postharvest losses and gaining } \\
\text { bargaining power in the value chain } \\
\text { leads farmers to engage in small-scale, } \\
\text { distributed collective action }\end{array}$ & $\begin{array}{l}\text { Systematic } \\
\text { literature review } \\
\text { and multiple case } \\
\text { study }\end{array}$ \\
\hline & $\begin{array}{l}\text { Miranda and } \\
\text { Grandori }\end{array}$ & $\begin{array}{l}\text { Agribusiness } \\
\text { conglomerates (global, } \\
\text { predominantly South } \\
\text { America) }\end{array}$ & $\begin{array}{l}\text { Strategies } \rightarrow \text { Institutions: Risk-reduction } \\
\text { strategies lead to integrated and } \\
\text { diversified farm structures }\end{array}$ & $\begin{array}{l}\text { Literature review } \\
\text { with empirical } \\
\text { illustrations }\end{array}$ \\
\hline & $\begin{array}{l}\text { Mupfasoni } \\
\text { et al. }\end{array}$ & $\begin{array}{l}\text { Integrated farmer groups } \\
\text { (Gitega and Muyinga } \\
\text { provinces, Burundi) }\end{array}$ & $\begin{array}{l}\text { Institutions } \rightarrow \text { Learning: Homogeneity of } \\
\text { motivations and identities in farmer } \\
\text { teams shape their collective } \\
\text { entrepreneurial capacity }\end{array}$ & $\begin{array}{l}\text { Descriptive } \\
\text { statistics and } \\
\text { single case study }\end{array}$ \\
\hline $\begin{array}{l}\text { Table } 1 \text {. } \\
\text { The papers of this } \\
\text { special issue in the new } \\
\text { organizational forms } \\
\text { framework }\end{array}$ & Zhuo and Ji & $\begin{array}{l}\text { E-commerce value chain } \\
\text { partnerships (Zhejiang } \\
\text { province, China) }\end{array}$ & $\begin{array}{l}\text { Institutions } \rightarrow \text { Strategies: } \\
\text { Need of trust between consumers and e- } \\
\text { commerce retailers leads to personal } \\
\text { interaction, online/offline transactions } \\
\text { and conflicts resolution as trust-building } \\
\text { strategies. }\end{array}$ & $\begin{array}{l}\text { Multiple case } \\
\text { study }\end{array}$ \\
\hline
\end{tabular}

beyond in the latest two decades. Their peculiar feature involves the development of smallscale, distributed storage facilities where farmers collectively store their harvest. Findings reveal that the condominiums thrived by effectively responding to new value chain challenges (e.g. demand quality, regularity of supply, competitive price and logistical complexity) and upgrading their postharvest process and market power in the value chain. In particular, farmers have formalized associations to govern the collective action for storing their commodities in a common facility nearby their farms. Hence, this paper illustrates how the strategic goals and resources of a new organizational form may drive the establishment of new institutions (Strategies $\rightarrow$ Institutions link in Figure 1).

The third paper of this special issue by Miranda and Grandori describes the key elements of farm structures, with a particular focus on what drives the emergence of agribusiness conglomerates. As a conceptual paper, it grounds its analysis in a literature review of the features and drivers of farm structures, supported with empirical illustrations from a variety of emerging economies, predominantly from South America. In this case, the new organization form under analysis includes agribusiness conglomerates, whose distinctive feature is their vertical or horizontal integration around farm structures. Building upon institutional economics theories, the authors argue that the reduction of risks associated with law enforcement and uncertainty in securing access to natural resources are fundamental drivers for integration and diversification, thus for the choice of larger organizational boundaries and a shareholder model of managing/owning farms. As such, in different ways relative to Guarnieri et al., also this paper illustrates how the strategic choices related to risk reduction shape the institutional arrangements that govern farms and their relationships with their value chain partners (Strategies $\rightarrow$ Institutions link in Figure 1).

Through the use of descriptive statistics and a single case study (i.e. Plan Intégré du Paysan in French or, in English, Integrated Farm Planning) from Burundi, the fourth paper of this special issue by Mupfasoni et al. focuses on the drivers of integrated farmer group formation. 
An integrated farmer group involves a small number of farmers (approximately 3-10per group) teaming up with the purpose of collectively developing sustainable land management practices. The findings from this study highlight that, among other drivers, the presence of homogeneous motivations and identities among partnering farmers are vital for the formation of entrepreneurial farmer teams. In other words, to create teams able to recombine resources innovatively to identify and seize opportunities for sustainable land management, the farmers teaming up benefit from a reciprocal selection based on preliminary, profound discussions on who they are and what they aspire to achieve. Thus, this paper illustrates how a specific type of new organization form develops collective entrepreneurial learning processes on the basis of their common identities (Institutions $\rightarrow$ Learning link in Figure 1).

The fifth and final paper of the specific issue by Zhuo and Ji focuses on e-commerce value chain partnerships that have recently flourished in the Chinese agrifood sector. The distinctive feature of this new organizational form involves an online platform governing transactions of food products between multiple suppliers and final consumers. E-commerce markets for high-quality agrifood products are rapidly growing in China, yet trust is an issue at the very heart of these initiatives because consumers can hardly verify product quality before purchase. On the basis of three empirical case studies, findings from this paper illustrate a variety of pathways through which trust among value chain partners can be achieved and maintained over time. Specifically, these trust-building pathways have in common three elements: building off-line personal interactions with buyers, establishing of online and off-line community-based events and setting mechanisms for a smooth resolution of disputes. Therefore, in the context of this special issue, the paper by Zhuo and Ji illustrates how the building of trust represents a powerful informal institutional mechanism to support the strategic goals of e-commerce value chain partnerships (Institutions $\rightarrow$ Strategies link in Figure 1).

\section{New organizational forms in emerging economies: taking stock and moving forward}

This special issue has been instrumental in bridging three different sets of theoretical lenses that may explain why, when and how new organizational forms emerge and evolve over time. These lenses involve institutional, strategy and learning theories. As the five papers in this issue demonstrate, as well as this editorial, the complex interplay among these three lenses has explanatory and perhaps even predictive power. In particular, we assert that the actors considering to (re)design new organizational forms need to analyze these three elements together because their organizations, and the people involved in them, need to adapt for changes in uncertain, turbulent and rapidly changing contexts where they are embedded. Hence, simultaneously considering institutional, strategic and learning as three key elements of analysis constitutes a remarkable contribution to the literature on new organizational forms, which so far focused predominantly either on institutions and strategies, but not on learning processes (Grandori, 2015, 2017; Menard, 2017, 2018), or on learning processes and institutions, yet not on strategies (Vellema and van Wijk, 2015; Schut et al., 2016).

Along with this theoretical contribution, we acknowledge that the road to make the study of new organizational forms societally relevant is still long to walk through. Only few contributions in this special issue - to some extent, Barzola et al. and Mufpasoni-looked at how new organizational forms take the SDGs into consideration into their strategic, institutional and learning processes. Since recent history has shown that the pursuit of private interests in partnerships does not lead per se to the accomplishment of the SDGs, we argue that organization studies need to take the SDGs into stronger consideration to become more relevant to the urgent societal and environmental issues faced by the agricultural and food sector worldwide. In bringing the SDGs at the core of the study of new 
organizational forms, further work will be required to bridge the existing gap between agribusiness management and international development studies. Therefore, questions that we would like to see urgently addressed in future studies involve: How these new organizational forms can enhance environmental and/or social innovation to achieve and support SDGs? In doing so, how do they take into account and address the social and environmental problems at hand? When do they work, and when do they fail to work, in supporting sustainability transitions or enhancing socioecological resilience? What are the key dimensions and indicators of their "success," effectiveness or impact? How do they navigate the dilemmas arising with seeking to combine private goals and the SDGs? What is the role of nonprofit associations and civil society in new organizational forms when combining these goals? Which role could technology, in particular information technology, play in transforming traditional organizations in food and agriculture into novel organizational forms that support the SDGs?

The knowledge gap that we recommend to address in future research is not only theoretical, but also methodological and - more profoundly - ontological. We recognize that most of the agribusiness management literature, including the articles that compose this special issue, has a strong positivist, and reductionist, nature (whereas Orr and Donovan's special issue in 2018 represents a remarkable exception). From a positivist perspective, complex mechanisms taking place within, across and outside organizations are predominantly reduced in sets of falsifiable cause-effect relationships. Yet, because of the complexity of the issues that they face in emerging economies, as well as their inherent novelty, we recognize that new organization forms evolve through a multitude of tensions, struggles and challenges. These tensions push new organizational forms to continually experiment, change and evolve. Hence, we recommend future research on new organizational forms in emerging economies to build more consciously upon a process ontology (Tsoukas and Chia, 2002; Van de Ven and Poole, 2005; Langley et al., 2013). Studying organizations as processes assumes that "(. . .) process is fundamental: The river is not an object but an everchanging flow; the sun is not a thing, but a flaming fire. Everything in nature is a matter of process, of activity, of change" (Rescher, 1996, p. 10). From this perspective, it would be insightful to study new organizational forms focusing on the practices that produce or impede change - rather than looking at organizational structures, strategies and knowledge (or capacities). A way to zoom into practices of change would involve, for example, studying the actions undertaken in organizations to navigate the challenges of combining private goals and the SDG through clashing institutional pressures (see Ferraro et al., 2015 for a brilliant example, yet not in the agricultural and food context).

Finally, moving forward in the study of new organizational forms in emerging economies will require, we argue, a deeper reflection on our positionality as scientists. Are we meant to study these novel organizations as "flies on the wall," that is, observing and seeking to understand them as they emerge, evolve, thrive or decline? Or are we, or should we, be part of these new organizational forms? For example, we know that universities and knowledge centers play a variety of roles in new organizational forms such as multistakeholder partnerships at global and local level (Trencher et al., 2014; Dentoni and Bitzer, 2015). This calls for other epistemological questions, such as: can or should we study organizational processes that we are partly involved in, not only as analysts, but also as stakeholders? While organization studies offer a variety of ways to rigorously undertake reflection-in-action (Yanow and Tsoukas, 2009) - from engaged scholarship to action research; from autoethnography to even research as activism - we are also aware of the challenges of interpreting organizational processes where we are deeply involved (Yanow and SchwartzShea, 2015). We recognize that challenging our traditional role of scientists in the study of new organizational forms does not represent an easy task, yet we deem it as necessary to meaningfully combine societal and scientific relevance. 


\section{References}

Abebe, G.K., Bijman, J. and Royer, A. (2016), "Are middlemen facilitators or barriers to improve smallholders' welfare in rural economies? Empirical evidence from Ethiopia”, Journal of Rural Studies, Vol. 43, pp. 203-213.

Antwi-Agyei, P., Dougill, A.J., Agyekum, T.P. and Stringer, L.C. (2018), "Alignment between nationally determined contributions and the sustainable development goals for West Africa", Climate Policy, Vol. 18 No. 10, pp. 1296-1312.

Barzola, C.L., Dentoni, D., Allievi, F., van der Slikke, T., Isubikalu, P., Oduol, J.B.A. and Omta, S.O. (2019), "Challenges of youth involvement in sustainable food systems: lessons learned from the case of farmers' value network embeddedness in Ugandan multi-stakeholder platforms", in Achieving the Sustainable Development Goals through Sustainable Food Systems, Springer, Cham, pp. 113-129.

Bengtsson, M. and Kock, S. (2000), "Coopetition in business Networks-to cooperate and compete simultaneously”, Industrial Marketing Management, Vol. 29 No. 5, pp. 411-426.

Bitzer, V. and Bijman, J. (2014), "Old oranges in new boxes? Strategic partnerships between emerging farmers and agribusinesses in South Africa”, Journal of Southern African Studies, Vol. 40 No. 1, pp. 167-183.

Bitzer, V. and Bijman, J. (2015), "From innovation to co-innovation? An exploration of African agrifood chains", British Food Journal, Vol. 117 No. 8, pp. 2182-2199.

Bitzer, V. and Glasbergen, P. (2015), "Business-NGO partnerships in global value chains: part of the solution or part of the problem of sustainable change?", Current Opinion in Environmental Sustainability, Vol. 12, pp. 35-40.

Bossle, M.B., De Barcellos, M.D. and Vieira, L.M. (2016), "Why food companies go green? The determinant factors to adopt eco-innovations", British Food Journal, Vol. 118 No. 6, pp. 1317-1333.

Chamberlain, W. and Anseeuw, W. (2019), "Inclusive businesses in agriculture: defining the concept and its complex and evolving partnership structures in the field", Land Use Policy, Vol. 83, pp. 308-322.

Clarke, A. and MacDonald, A. (2019), "Outcomes to partners in multi-stakeholder cross-sector partnerships: a resource-based view", Business and Society, Vol. 58 No. 2, pp. 298-332.

Cucchi, C., Dentoni, D., Lubberink, R. and Gartner, W.B. (2019), “Organizing with the magic in between two organized worlds: paradoxical responses enacting agency and fatalism in Chewa dairy communities", paper presented at the 4th Entrepreneurship as Practice (EaP) conference, Audiencia Business School, Nantes (France), April 3-6, 2019.

Das, T.K. and Teng, B.S. (2000), "A resource-based theory of strategic alliances", Journal of Management, Vol. 26 No. 1, pp. 31-61.

Dentoni, D. and Bitzer, V. (2015), "The role (s) of universities in dealing with global wicked problems through multi-stakeholder initiatives", Journal of Cleaner Production, Vol. 106, pp. 68-78.

Dentoni, D. and Dries, L. (2015), Private Sector Investments to Create Market-Supporting Institutions: The Case of Malawian Agricultural Commodity Exchange No. 330-2016-13604, Paper presented at the Agricultural and Applied Economics Association (AAEA) Annual Meetings, San Francisco, CA, July 2015.

Dentoni, D., Bitzer, V. and Pascucci, S. (2016), "Cross-sector partnerships and the co-creation of dynamic capabilities for stakeholder orientation”, Journal of Business Ethics, Vol. 135 No. 1, pp. 35-53.

Dentoni, D., Bitzer, V. and Schouten, G. (2018), "Harnessing wicked problems in multi-stakeholder partnerships", Journal of Business Ethics, Vol. 150 No. 2, pp. 333-356.

Ferraro, F., Etzion, D. and Gehman, J. (2015), "Tackling grand challenges pragmatically: robust action revisited”, Organization Studies, Vol. 36 No. 3, pp. 363-390.

Grandori, A. (2015), "Improving organization forms in the agri-food industry", British Food Journal, Vol. 117 No. 10, pp. 2418-2434.

\section{organization \\ forms in emerging \\ economies}


Grandori, A. (2017), "Linnaeus in the jungle: configurational lenses for discerning forms of economic organization in agri-business", in It's a Jungle Out There-The Strange Animals of Economic Organization in Agri-Food Value Chains, Wageningen Academic Publishers, Wageningen, pp. 209-222.

Isubikalu, P. (2007), Stepping-stones to Improve upon Functioning of Participatory Agricultural Extension Programmes: Farmer Field Schools in Uganda, Wageningen Academic Publishers, Wageningen.

Ji, C., Guo, H., Jin, S. and Yang, J. (2017), "Outsourcing agricultural production: evidence from rice farmers in Zhejiang province", PloS One, Vol. 12 No. 1, pp. 1-16.

Kawarazuka, N. and Kharchandy, B. (2019), A Rapid Assessment of Farmer Business Schools from a Gender Perspective in Meghalaya, India. International Potato Center, La Molina.

Langley, A.N.N., Smallman, C., Tsoukas, H. and Van de Ven, A.H. (2013), "Process studies of change in organization and management: unveiling temporality, activity, and flow", Academy of Management Journal, Vol. 56 No. 1, pp. 1-13.

Likoko, E. and Kini, J. (2017), "Inclusive business-a business approach to development", Current opinion in environmental sustainability, Vol. 24, pp. 84-88.

Lutz, C. and Tadesse, G. (2017), “African farmers' market organizations and global value chains: competitiveness versus inclusiveness", Review of Social Economy, Vol. 75 No. 3, pp. 318-338.

Ménard, C. (2004), "The economics of hybrid organizations", Journal of Institutional and Theoretical Economics JITE, Vol. 160 No. 3, pp. 345-376.

Ménard, C. (2017), "Meso-institutions: the variety of regulatory arrangements in the water sector", Utilities Policy. Vol. 49, pp. 6-19.

Ménard, C. (2018), "Organization and governance in the agrifood sector: how can we capture their variety?", Agribusiness, Vol. 34 No. 1, pp. 142-160.

Naziri, D. and Enalbes, C.J. (2019), Connecting Smallholder Root and Tuber Growers to Markets through Farmer Business Schools, International Potato Center, La Molina.

North, D.C. (1990), Institutions, Institutional Change and Economic Performance, Cambridge University Press, Cambridge and New York.

North, D.C. (1991), "Institutions", The Journal of Economic Perspectives, Vol. 5 No. 1, pp. 97-112.

Orr, A., Donovan,J. and Stoian, D. (2018), "Smallholder value chains as complex adaptive systems: a conceptual framework", Journal of Agribusiness in Developing and Emerging Economies, Vol. 8 No. 1, pp. 14-33.

Rescher, N. (1996), Process Metaphysics: An Introduction to Process Philosophy, Suny Press, Albany, NY.

Royer, A., Bijman, J. and Abebe, G.K. (2017), “Cooperatives, partnerships and the challenges of quality upgrading: a case study from Ethiopia, Journal of Co-operatives Organization and Management, Vol. 5 No. 1, pp. 48-55.

Schouten, G. and Glasbergen, P. (2011), "Creating legitimacy in global private governance: the case of the roundtable on sustainable palm oil”, Ecological Economics, Vol. 70 No. 11, pp. 1891-1899.

Schut, M., van Asten, P., Okafor, C., Hicintuka, C., Mapatano, S., Nabahungu, N.L. and Sartas, M. (2016), "Sustainable intensification of agricultural systems in the Central African Highlands: the need for institutional innovation", Agricultural Systems, Vol. 145, pp. 165-176.

Scott, W.R. (1987), "The adolescence of institutional theory", Administrative Science Quarterly, Vol. 32 No. 4, pp. 493-511.

Thornton, P.H. and Ocasio, W. (2008), "Institutional logics", The Sage handbook of organizational institutionalism, Vol. 840, pp. 99-128.

Trencher, G., Bai, X., Evans, J., McCormick, K. and Yarime, M. (2014), "University partnerships for codesigning and co-producing urban sustainability”, Global Environmental Change, Vol. 28, pp. 153-165.

Tsoukas, H. and Chia, R. (2002), "On organizational becoming: rethinking organizational change", Organization Science, Vol. 13 No. 5, pp. 567-582. 
Van de Ven, A.H. and Poole, M.S. (2005), "Alternative approaches for studying organizational change", Organization Studies, Vol. 26 No. 9, pp. 1377-1404.

Vellema, S. and van Wijk, J. (2015), "Partnerships intervening in global food chains: the emergence of cocreation in standard-setting and certification",Journal of Cleaner Production, Vol. 107, pp. 105-113.

Vieira, L.M., Hoppe, A. and Schneider, L.C. (2016), "Multi-stakeholder initiative for sustainable beef production standards", in A Stakeholder Approach to Managing Food, Routledge, London, pp. 35-46.

Voegtlin, C. and Scherer, A.G. (2017), Responsible innovation and the innovation of responsibility: governing sustainable development in a globalized world, Journal of Business Ethics, Vol. 143 No. 2, pp. 227-243.

Yanow, D. and Schwartz-Shea, P. (2015), Interpretation and Method: Empirical Research Methods and the Interpretive Turn, Routledge, London.

Yanow, D. and Tsoukas, H. (2009), "What is reflection-in-action? A phenomenological account", Journal of Management Studies, Vol. 46 No. 8, pp. 1339-1364.

\section{Further reading}

Orr, A. and Donovan, J. (2018), "Introduction to special issue: smallholder value chains as complex adaptive systems", Journal of Agribusiness in Developing and Emerging Economies, Vol. 8 No. 1, pp. 2-13.

\section{Author Affiliations}

Domenico Dentoni, Business Management and Organization Group, Wageningen University, Wageningen, The Netherlands.

Jos Bijman, Business Management and Organization Group, Wageningen University, Wageningen, The Netherlands.

Marilia Bonzanini Bossle, Instituto Federal de Educação, Ciência e Tecnologia do Rio Grande do Sul, IFRS, Campus Viamão, Brazil.

Sera Gondwe, Department of Agribusiness Management, Lilongwe University of Agriculture and Natural Resources (LUANAR), Lilongwe, Malawi.

Prossy Isubikalu, Department of Extension and Innovation Studies, College of Agriculture and Environmental Sciences, Makerere University, Kampala, Uganda.

Chen Ji, Agricultural Economics and Management at School of Management, Zhejiang University, Hangzhou, China.

Chintan Kella, Tilburg School of Economics and Management, Tilburg University, Tilburg, The Netherlands.

Stefano Pascucci, University of Exeter Business School, Panryn Campus, Exeter, UK.

Annie Royer, Laval University, Quebec, Canada.

Luciana Vieira, Fundacao Getulio Vargas Escola de Administracao de Empresas de Sao Paulo, Sao Paulo, Brazil.

\section{Corresponding author}

Domenico Dentoni can be contacted at: domenico.dentoni@wur.nl

For instructions on how to order reprints of this article, please visit our website:

www.emeraldgrouppublishing.com/licensing/reprints.htm

Or contact us for further details: permissions@emeraldinsight.com 